Interactive comment on "A17-year dataset of surface water fugacity of $\mathrm{CO}_{2}$, along with calculated $\mathrm{pH}$, Aragonite saturation state, and air-sea $\mathrm{CO}_{2}$ fluxes in the Northern Caribbean Sea" by Rik Wanninkhof et al.

\title{
Rik Wanninkhof et al.
}

rik.wanninkhof@noaa.gov

Received and published: 3 May 2020

Please find attached the response to reviewer's comments and the edited MS with track changes. We appreciate the thorough review and helpful suggestions.

Please also note the supplement to this comment: 
Interactive comment on Earth Syst. Sci. Data Discuss., https://doi.org/10.5194/essd-2019-245, 2020.

\section{ESSDD}

Interactive comment 